\title{
Dry thermophilic semi-continuous anaerobic digestion of food waste: Performance evaluation, modified Gompertz model analysis, and energy balance
}

\author{
Dinh Duc Nguyen ${ }^{a, b}$, Soon Woong Chang ${ }^{b}$, Seong Yeob Jeong ${ }^{b}$, Jaehoon Jeung ${ }^{b}$, Sungsu Kim ${ }^{b}$, \\ Wenshan $\mathrm{Guo}^{c}$, Huи Hao $\mathrm{Ngo}^{c}$
}

${ }^{a}$ Duy Tan University, Da Nang, Viet Nam

${ }^{\mathrm{b}}$ Department of Environmental Energy \& Engineering, Kyonggi University, Republic of Korea

${ }^{c}$ Centre for Technology in Water and Wastewater, School of Civil and Environmental Engineering, University of Technology, Sydney (UTS), Australia

\section{Highlights}

- Energy self-sufficiency/energy recovery with thermophilic DScAD of FW was evaluated.

- The maximum biogas production rate was positively influenced by OLRs.

- Maximum (average) electrical energy recoverable from a 1 tons of FW was $1050 \mathrm{~kW} \mathrm{h.}$

- Thermophilic DScAD can substantially reduce the VS and recover energy to serve itself.

- A modified Gompertz model fitted well with the experimental results for all phases.

\begin{abstract}
A thermophilic, dry semi-continuous anaerobic digestion (DScAD) method was used to effectively transform food waste (FW) into renewable energy. This study aims to thoroughly evaluate the system performance and model simulation to predict biogas production, intermediate products and their outcomes, energy recovery potential, and energy balance, while operating with organic loading rates ranging from 2.3 to $9.21 \mathrm{~kg}-\mathrm{TS} / \mathrm{m}^{3}$ day. The results indicate that volatile solids (VS) reduction and biogas production both improved as the organic loading rates (OLR) increased, and the cost of FW valorization remained low. The greatest VS reduction achieved was $87.01 \%$, associated with $170 \mathrm{~m}^{3}$ of biogas yield per ton of sludge $\left(69 \%\right.$ methane) at an ORL of $9.21 \pm 0.89 \mathrm{~kg}-\mathrm{TS} / \mathrm{m}^{3}$ day $(8.62 \pm 0.34 \mathrm{~kg}$ $\mathrm{VS} / \mathrm{m}^{3}$ day) although the amounts of ammonia (3700 mg/L), hydrogen sulfide (420 ppm), and total volatile fatty acids $(7101 \mathrm{mg} / \mathrm{L})$ during fermentation were relatively high. Furthermore, $75 \%$ of total energy requirement for the system could be recovered via biomethane production, resulting in a considerably reduced specific energy supply $(\mathrm{kW} \mathrm{h/ton} \mathrm{of} \mathrm{treating}$ FW). The results suggest that a modified Gompertz model is suitable for estimating the biogas and methane production potential and rate. The results also reveal that the DScAD of $\mathrm{FW}$ at $55^{\circ} \mathrm{C}$ is a reliable, stable, and robust option for both solids reduction and energy recovery via biogas generation.
\end{abstract}

Keywords: Organic loading rate; Thermophilic dry anaerobic digestion; Food waste; Biogas production; Modified Gompertz equation 



\section{Introduction}

Organic waste has increasingly been regarded as an abundant biomass energy resource and its availability is not closely linked to fluctuations in economic conditions and politics worldwide [1] and [2]. Organic waste has great potential in generating significant amount of renewable energy [3] and thus contributing to solving the world's energy problems [1],[2] and [4]. Of the various types of organic wastes, food waste (FW), known for its high organic content, is a major portion (25-52.6\%) of municipal solid wastes [5], [6],[7] and [8]. In South Korea, the amount of FW generated every day increased from 11,398 tons per day in 2003 to 13,697 tons per day in 2014, corresponding to an increase from 22.5 to $29.1 \%$ of the municipal solid waste stream [9].

In recent years, as a result of the new economic policies dealing with the issues of energy, environment, and emissions, the South Korean government has invested a great deal of effort and funds in developing technologies for the conversion of waste to energy[10]. The government's target for 2050 is to have $20 \%$ of the country's energy demand generated by renewable resources [11]. Conventional approaches including ocean dumping, sanitary landfills, incineration, recycling, and composting for the treatment of food waste for sustainable waste management and/or potential energy recovery have been tried and wellstudied. However, these methods are no longer attractive because of the environmental concerns, their higher cost, and government regulations [12],[13] and [14]. Dry anaerobic digestion (AD) technology, on the other hand, is one of the most commonly used organic waste treatment methods due to its economic viability, stability, potential by-products such as fertilizers, and energy recovery advantages. The dry AD technology has the ability of treating high amounts of and a wide range of solid waste (up to 40\%) and achieves high organic matter reduction and biogas production rates [10], [15], [16], [17], [18] and [19].

While previous studies on dry anaerobic digestion processes conducted mainly in Europe and the US are informative [20] and [21], many issues regarding the influence of local environmental conditions on the process [15], operating conditions, food waste characteristics [2], organic loading rates, solids retention time, and inhibition problems [16] remain to be clarified [21] and [22]. In particular, there is little information on the dry $\mathrm{AD}$ of FW [21]. The energy balance aspect of the process [23], the use of a modified Gompertz model to evaluate the system performance, and the interaction between the operating parameters have also received little or no attention. Consequently, the commercialscale use of this process, as needed to produce renewable energy from the organic fraction of FW in South Korea, has not yet been developed or extensively investigated [16].

In this study, the performance of the bench-scale, dry thermophilic semi-continuous anaerobic digestion (DScAD) of food waste was thoroughly evaluated under different operational conditions of organic loading rates (OLRs), hydraulic retention times (HRTs), and solid concentrations. The potential for biogas and methane production from a $\mathrm{FW}$ treatment system via dry thermophilic AD under varying operating conditions was also evaluated and experimental results were verified by a modified Gompertz model. In addition, 
energy requirements, energy recovery, and the cost of the dry thermophilic AD system were calculated for various test conditions.

\section{Materials and methods}

\subsection{Substrate and seed organisms}

Under this initiative, approximately $60-65 \mathrm{~kg}$ of FW was collected from the student restaurants in Kyonggi University, from 3 to $5 \mathrm{pm}$. The collected FW was crushed into pieces with a diameter of less than $2 \mathrm{~mm}$ and used as substrate for the feasibility study. The inoculum was collected from the dry FW digestion plant in Pusan City, South Korea. The characteristics of the FW and inoculum are shown in Table 1.

Table 1. Characteristics of the FW and inoculum.

\begin{tabular}{llll}
\hline Parameter & Unit & Food waste & Inoculum \\
\hline pH & - & 4.91 & 7.62 \\
Total solids, TS & $\%$ & 23.02 & 20.02 \\
Volatile solids, VS & $\%$ & 20.55 & 12.59 \\
VS/TS & $\%$ & 91.53 & 69.54 \\
Total chemical oxygen demand, TCOD & $\mathrm{mg} / \mathrm{kg}$ & 220,000 & 72,000 \\
Total nitrogen, TN & $\mathrm{mg} / \mathrm{kg}$ & 3650 & 4200 \\
Ammonia nitrogen, NH $\mathbf{4}-\mathbf{N}$ & $\mathrm{mg} / \mathrm{kg}$ & 900 & 1800 \\
C/N ratio & - & $14.58-22.00$ & - \\
\hline
\end{tabular}

\subsection{Experimental setup and procedure}

Fig. 1 shows the outline of the dry semi-continuous anaerobic digester system used in this study. The digester was continuously mixed at $30 \mathrm{rpm}$ to ensure the homogeneity of the microbial communities, substrate particles, nutrients, and temperature for the growth of anaerobic microorganisms. The digester was equipped with a hot water jacket system, which was thermostatically controlled by the recirculating pump. In addition, all of the digester's features, including the heat transfer device, recirculating pump, agitator, $\mathrm{pH}$ and temperature sensors, and thermometer were automatically monitored and controlled by a programmable logic controller. There was also a manual operating mode. 

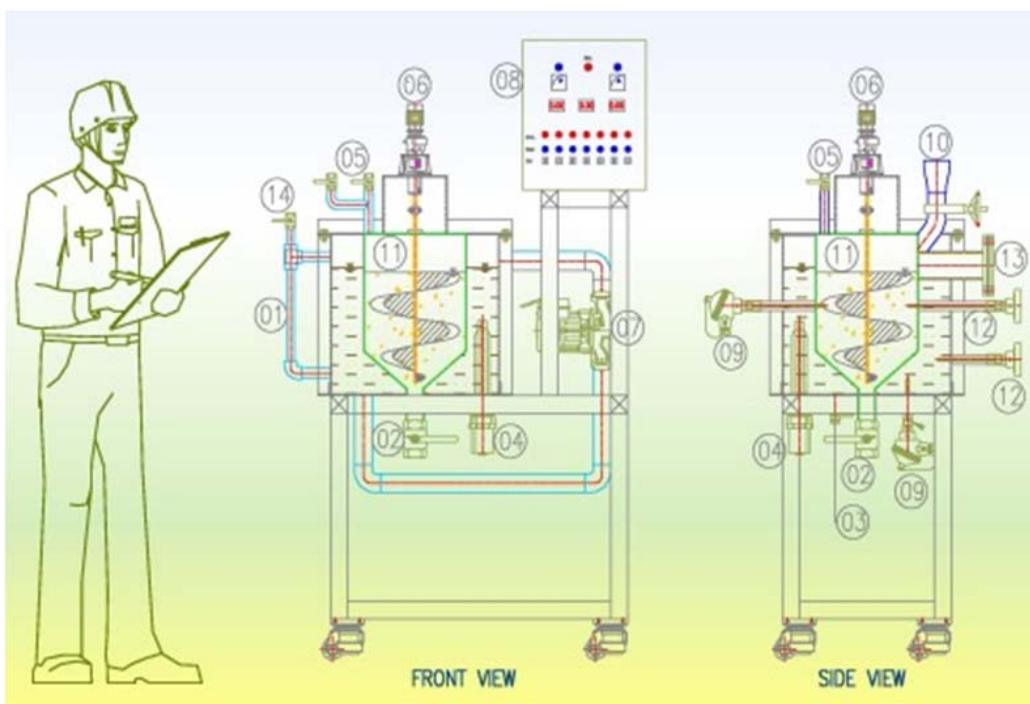

(01) Woter level gouge

(12) Sludge droin

(03) Water heater discharge

(04) Electric heater

(05) Gos outlet/collection

(06) Agitator

(07) Recirculating pump

(08) Control panel

(09) Temp. sensor

(10) Sludge inlet

(11) Anaerobic digester

(12) Thermometer

(13) Inspection window

(14) Woter inlet

Fig. 1. A schematic of the dry semi-continuous anaerobic digester system.

The total volume of the thermophilic dry anaerobic digester was $20 \mathrm{~L}$, with a working volume of $10 \mathrm{~L}$. The digester was inoculated with $10 \mathrm{~L}$ of digestate obtained from the full-scale FW digestion plant and purged with $\mathrm{N}_{2}$ gas for $10 \mathrm{~min}$ in order to create anaerobic conditions.

To evaluate the digester's stability and performance the system was degassed [24] for eight days and no food waste was injected into the digester during this time. Then experiments were conducted to investigate four operational conditions with different organic loading rates (OLRs). The digester was fed raw food waste at different rates to achieve OLRs of $2.3 \pm 0.22 \mathrm{~kg}-\mathrm{TS} / \mathrm{m}^{3}$ day (Phase 1), $3.82 \pm 0.37 \mathrm{~kg}-\mathrm{TS} / \mathrm{m}^{3}$ day (Phase 2), $7.67 \pm 0.74 \mathrm{~kg}$ $\mathrm{TS} / \mathrm{m}^{3}$ day (Phase 3 ), and $9.21 \pm 0.89 \mathrm{~kg}-\mathrm{TS} / \mathrm{m}^{3}$ day (Phase 4 ). These OLRs corresponded to four hydraulic retention times (HRTs) of 100 days, 60 days, 30 days, and 25 days, respectively, at a fixed solid content of $20 \% \mathrm{TS}$, and a carbon-to-nitrogen ratio $(\mathrm{C} / \mathrm{N})$ of 14.6-22.0.

The dry anaerobic digester was operated at $38^{\circ} \mathrm{C}$ during Phase 1 and 2, and then during Phase 3 , the temperature was gradually increased from $38{ }^{\circ} \mathrm{C}$ to $55^{\circ} \mathrm{C}$ (thermophilic conditions) at the rate of $1{ }^{\circ} \mathrm{C}$ every 2 days.

\subsection{Analytical methods}

\subsubsection{Sampling and analysis}

To evaluate the effects of an increase in OLR on digester performance, samples of the influent and effluent digestion sludge, as well as the biogas and methane content, were collected and analyzed daily during the study period.

Operational parameters, including concentrations of total solids (TS), volatile solids (VS), total nitrogen $(\mathrm{TN})$, ammonium nitrogen $\left(\mathrm{NH}_{4}-\mathrm{N}\right)$, total phosphorus $(\mathrm{TP})$, total chemical oxygen demand (TCOD), alkalinity (Alk.) and $\mathrm{pH}$ were determined according to Standard 
Methods [25]. The volume of biogas produced in the reactor was measured using a wet gas meter (W-NK-0.5, Shinagawa Corporation, Japan) and a Tedlar ${ }^{\circledR}$ bag for gas sampling. The analysis of the gas composition (methane $\left(\mathrm{CH}_{4}\right)$, carbon dioxide $\left(\mathrm{CO}_{2}\right)$, ammonia gas $\left(\mathrm{NH}_{3}-\right.$ gas), and hydrogen sulfide $\left(\mathrm{H}_{2} \mathrm{~S}\right.$-gas)) was carried out using a biogas analyzer (GSR-3100, Sensoronic Co., Ltd., South Korea). Volatile fatty acids (VFA) were analyzed by gas chromatography (GC) (Agilent 7890A, Agilent Technologies, Inc., USA), equipped with a flame ionization detector and SGE BP21 capillary wax column $(25 \mathrm{~m}$ Length $\times 0.53 \mathrm{~mm}$ ID $\times 0.5 \mu \mathrm{m}$ df, Agilent technologies, Inc., USA) and with nitrogen as a carrier gas. Approximately $2 \mu \mathrm{L}$ of each sample was injected into GC. The initial temperature of the GC column was $60^{\circ} \mathrm{C}$, which was increased at the rate of $5{ }^{\circ} \mathrm{C} / \mathrm{min}$ to $120^{\circ} \mathrm{C}$. Once the temperature reached $120^{\circ} \mathrm{C}$, it was once again increased at the rate of $10{ }^{\circ} \mathrm{C} / \mathrm{min}$ to a final temperature of $230{ }^{\circ} \mathrm{C}$. The injector temperature was set at $200{ }^{\circ} \mathrm{C}$, while that of the flame ionization detector was set at $230^{\circ} \mathrm{C}$.

\subsubsection{Modified Gompertz model analysis}

The modified Gompertz equation (Eq. (1)) [26], [27], [28] and [29] was used to analyze and describe the biogas and biomethane production during each phase:

$$
M(t)=P \times \exp \left\{-\exp \left[\frac{R_{\max } \exp (1)}{P}(\lambda-t)+1\right]\right\}
$$

In Eq. (1), $M(t)$ is the cumulative biogas or methane production (L) at a given time $\mathrm{t}$ (days); $\mathrm{Rm}$ is the maximum specific methane production rate ( $\mathrm{L} / \mathrm{kg}-\mathrm{VS}_{\text {added }}$ day); $\mathrm{P}$ is the biogas or methane production potential ( $\left.\mathrm{L} / \mathrm{kg}-\mathrm{VS}_{\mathrm{added}}\right)$; and $\lambda$ is the lag phase time (days).

\subsubsection{Data analysis}

The statistical significance of the Modified Gompertz model was evaluated by Fisher's statistical test in the analysis of variance (ANOVA), using Origin 8.1 (OriginLab Corporation, USA) and Microsoft Excel 2010, with an Excel add-in program.

\section{Results and discussion}

\subsection{Dry digester performance and evaluation}

\subsubsection{Biogas production and volatile solids reduction}

The impact of an increase in OLR achieved by feeding different raw food waste ratios, on the performance of the dry AD process during operation were evaluated and optimized.

Overall, the results show that during the course of operations the $\mathrm{pH}$ value in the dry anaerobic digester varied from 6.6 to 8.1 , which was favorable for the active metabolic processes and the synthesis of new biomass, despite increasing OLR. Methane gas was detected in the first days of each phase, proving that the digester had started up well, with the anaerobic microbial populations rapidly adapting to the new environmental conditions. The average daily production of biogas/methane by a digester, and its ability to biodegrade 
organic matter increased proportionally with increasing OLR. However, the daily production of biogas/methane and the VS reduction by the digester often experienced a period of instability following each increase in the OLR. Following the initial period of instability, the digester tended to self-regulate in a stable condition (Fig. 2a). The results showed that the start-up periods needed for the digester to reach a stable level of activity were different, depending on the operating load of organic matter. It is worth noting that the time needed to achieve the stable methane production was longer than the time needed to achieve the stable VS reduction.

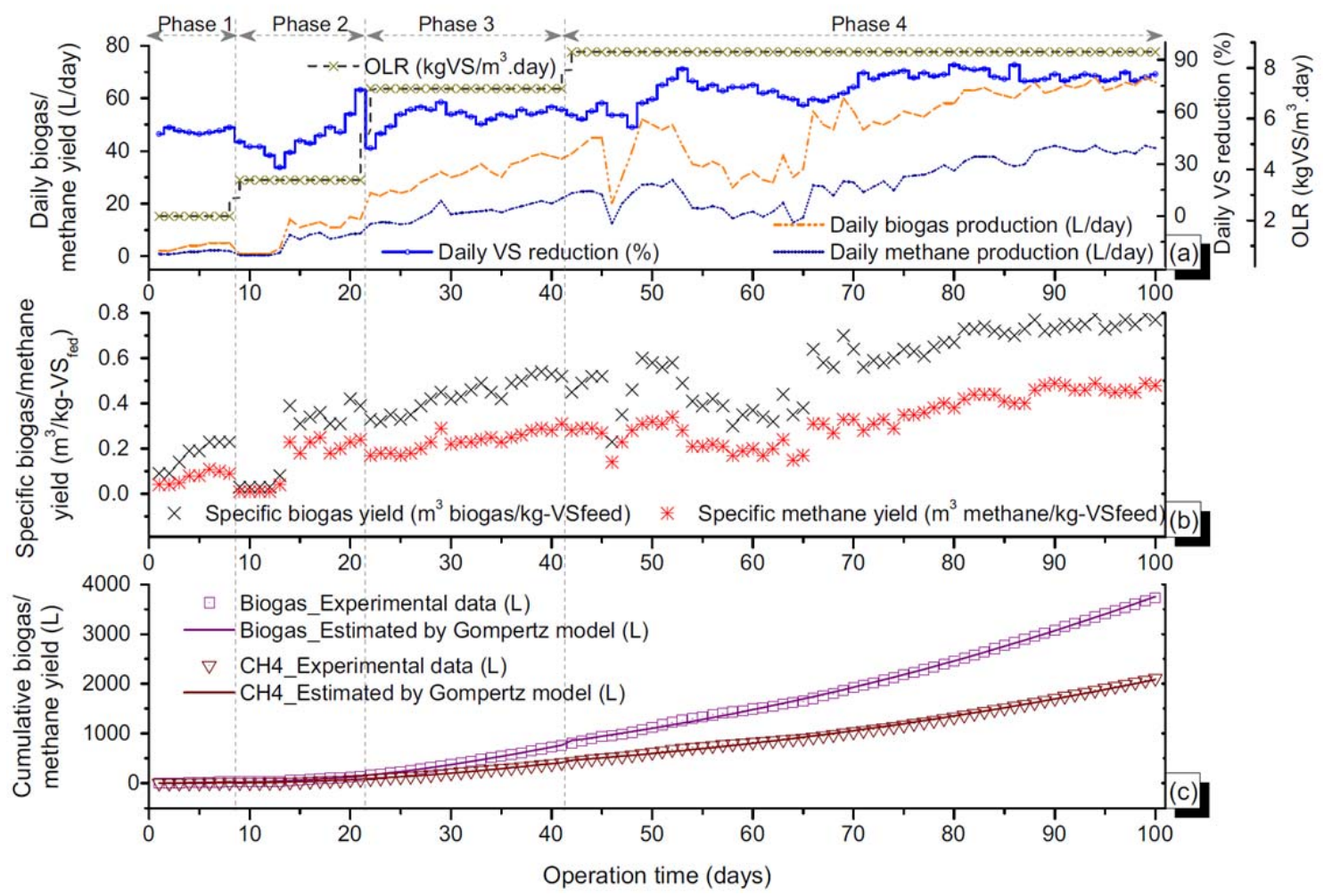

Fig. 2. Variation of the VS reduction, biogas yield, and production rate under different organic loading rates.

During the stable periods (steady-state conditions), the specific biogas, methane yield, and VS removal efficiency in Phase 1 were in the range of $0.14-0.23 \mathrm{~m}^{3}$-biogas $/ \mathrm{kg}-\mathrm{VS}_{\text {fed }}, 0.08$ $0.11 \mathrm{~m}^{3}$-methane $/ \mathrm{kg}-\mathrm{VS}_{\text {fed }}$, and $47.22-50.93 \%$, respectively. Corresponding values for Phase 2 were $0.31-0.42 \mathrm{~m}^{3}$-biogas $/ \mathrm{kg}-\mathrm{VS}_{\text {fed }}, 0.18-0.25 \mathrm{~m}^{3}$-methane $/ \mathrm{kg}-\mathrm{VS}_{\text {fed }}$, and $41.76-72.63 \%$ respectively. For Phase 3, the corresponding values were $0.42-0.54 \mathrm{~m}^{3}-\mathrm{biogas} / \mathrm{kg}-\mathrm{VS}_{\mathrm{fed}}$, $0.23-0.31 \mathrm{~m}^{3}$-methane $/ \mathrm{kg}-\mathrm{VS}_{\mathrm{fed}}$, and $52.92-62.67 \%$, respectively. Finally, the values for Phase 4 were $0.72-0.79 \mathrm{~m}^{3}-$ biogas $/ \mathrm{kg}-\mathrm{VS}_{\text {fed }}, \quad 0.4-0.49 \mathrm{~m}^{3}-$ methane $/ \mathrm{kg}-\mathrm{VS}$ fed, and $77.73-$ $87.01 \%$, respectively (Fig. $2 b$ ).

The results also showed that the highest average biological organic matter removal efficiency during the stable periods was $81.19 \%$ (Stdev. $\pm 2.68 \%$ ) in Phase 4 , while the removal 
efficiencies in Phase 3, 2, and 1 were $58.62 \pm 2.82 \%, 51.7 \pm 10.78 \%$, and $48.77 \pm 1.27 \%$, respectively.

Similarly, the highest average biogas production rate was observed in Phase 4, with $0.75 \pm 0.02 \mathrm{~m}^{3}$-biogas $/ \mathrm{kg}-\mathrm{VS}_{\text {fed }}$ (containing $61.89 \pm 2.74 \%$ of methane). This was $1.53,2.14$, and 3.75 times higher than the biogas production rates in Phase 3, 2, and 1, respectively. These findings suggest that biogas and methane yields and the VS removal efficiency were significantly affected by the OLR.

The estimated amount of average biogas produced ( $\mathrm{m}^{3}$-biogas/ton of $\mathrm{FW}$ ) and methane content (\%) in the dry anaerobic digester during steady-state conditions were $43.33 \pm 8.16 \mathrm{~m}^{3}$-biogas/ton of FW $(42.83 \% \pm 2.79 \%$ methane $), 74.87 \pm 9.75 \mathrm{~m}^{3}$-biogas/ton of FW $(62.86 \% \pm 5.24 \%$ methane $), \quad 104.83 \pm 9.15 \mathrm{~m}^{3}$-biogas $/$ ton of $\mathrm{FW}(53.3 \% \pm 2.76 \%$ methane) and $162.14 \pm 4.58 \mathrm{~m}^{3}$-biogas/ton of FW $(61.89 \% \pm 2.74 \%$ methane) for Phase 1,2 , 3 , and 4, respectively. Compared to the previous studies on food waste treatment (e.g. 13.32 and $11.85 \mathrm{~m}^{3}$-biogas/ton [30]; $0.317 \mathrm{~m}^{3}$-methane/kg-VS and $0.446 \mathrm{~m}^{3}$-methane/kg-VS [31], $0.435 \mathrm{~m}^{3}$-methane/kg-VS [2]), the digester in this study not only operated with high OLR for faster hydrolysis of the organic matter, but also achieved greater energy recovery.

Based on the information above, we conclude that the design and available operation options of the thermophilic dry anaerobic digester are well-suited to the enhanced biological organic matter removal along with increased renewable energy production at high OLR. This leads to the use of less space, less capital investment, a simpler installation process, and cheaper operating and maintenance costs.

\subsubsection{Intermediate products and its effects}

Volatile fatty acids (VFAs) are intermediate products of the anaerobic digestion process of organic compounds to methane [32], [33] and [34]. Their accumulation is one of the parameters that have a significant effect on overall digester performance [32], [35], [36],[37] and [38]. However, during this study we did not observe any noticeable signs of impact on the operation of the DScAD process or the biogas production, even when the total VFA concentration reached a peak of $7.101 \mathrm{~g} / \mathrm{L}$ at the OLR of $8.62 \mathrm{~kg}-\mathrm{VS} / \mathrm{m}^{3}$ day (HRT 25 days). This robust performance indicates that the system was operating properly.

The effect of OLRs on the VFA product concentration at different phases is shown in Fig. 3. The results show similar tendencies to those of the biogas production and the VS reduction and the VFA generation tends to increase gradually with increasing OLR. Additionally, acetic acid and propionic acid accounted for the majority of VFAs, 36.6\%-69.9\% (average $52.39 \% \pm 9.39 \%$ ) and $19.7 \%-55.6 \%$ (average $33.85 \pm 9.84$ ), respectively. These parameters are reliable indicators for evaluating and identifying the effectiveness of the digester during biogas production [32], [36] and [39]. Fig. 3demonstrates the relative prevalence of different VFA fractions for all phases by the following order: acetic acid $>$ propionic acid $>$ butyric 
acid $>$ other acids (other VFAs). As the OLR increased, the average total concentration of VFAs during steady-state conditions of Phase 1, 2, 3, and 4 were $148 \mathrm{mg} / \mathrm{L}, 284 \mathrm{mg} / \mathrm{L}$, $2185 \mathrm{mg} / \mathrm{L}$, and $6288 \mathrm{mg} / \mathrm{L}$, respectively (Fig. 3).

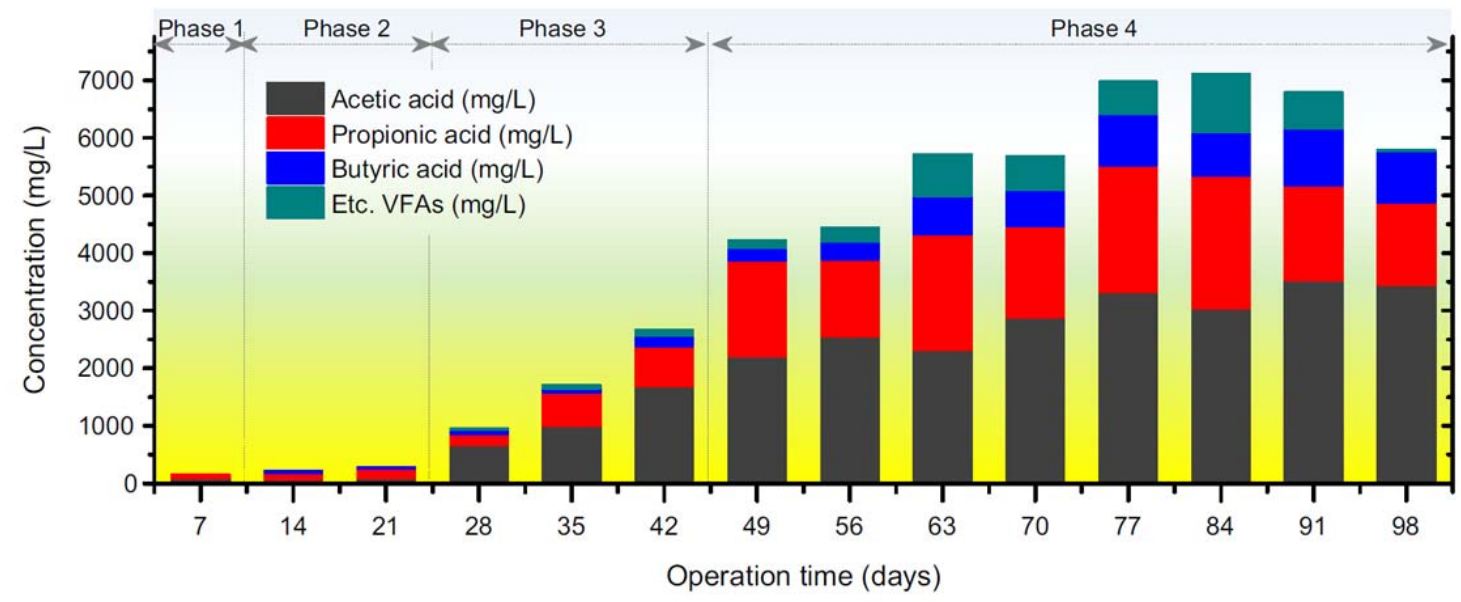

Fig. 3. Variation in the composition of VFA during operation at different organic loading rates.

Phase 4 was conducted to evaluate and optimize the dry digester performance under thermophilic conditions. The results showed that total VFA concentrations increased gradually to a maximum value of $7101 \mathrm{mg}-\mathrm{VFAs} / \mathrm{L}$ (containing $42.97 \%$ acetic acid, 32.5\% propionic acid, and $10.58 \%$ butyric acid), and then fell to the stable value of approximately $6288 \mathrm{mg}$-VFAs/L (containing 55.87\% acetic acid, 24.44\% propionic acid, and $15.08 \%$ butyric acid). Interestingly, during Phase 4 , the period of time from the start of the phase to the time the total VFA concentration reached peak value was also the time during which the digester shifted to a steady state of biogas production (Figs. 2a and 3).

Over the course of Phase 4, acetic acid concentration was always higher than propionic acid concentration. During steady state, the acetic acid to propionic acid ratio was approximately 2.27; the concentrations of acetic acid, propionic acid, and butyric acid were $3494 \mathrm{mg} / \mathrm{L}$, $1536 \mathrm{mg} / \mathrm{L}$, and $946 \mathrm{mg} / \mathrm{L}$, respectively. This ratio is regarded as a valid parameter to assess the digester's balance and stability [36] and [40].

The variations of hydrogen sulfide $\left(\mathrm{H}_{2} \mathrm{~S}\right.$-gas $)$ and ammonia $\left(\mathrm{NH}_{3}\right.$-gas $)$ formation seen in the thermophilic dry anaerobic digester during operation under different organic loading rates are shown in Fig. 4. $\mathrm{H}_{2} \mathrm{~S}$-gas and $\mathrm{NH}_{3}$-gas, commonly generated during the anaerobic digestion of sludge, are inhibitory substances and can discourage microorganisms' activity in anaerobic digesters [41] and [42]. $\mathrm{H}_{2} \mathrm{~S}$-gas and $\mathrm{NH}_{3}$-gas products are formed from the bacterial hydrolysis of organic compounds [43] and [44]; both can hinder metabolic processes in microorganisms [41] and [45]. According to [44], 25-90\% of methanogenic activity inhibition occurs when concentrations of $150 \mathrm{mg}-\mathrm{H}_{2} \mathrm{~S} / \mathrm{L}$ are present in an anaerobic digester. 


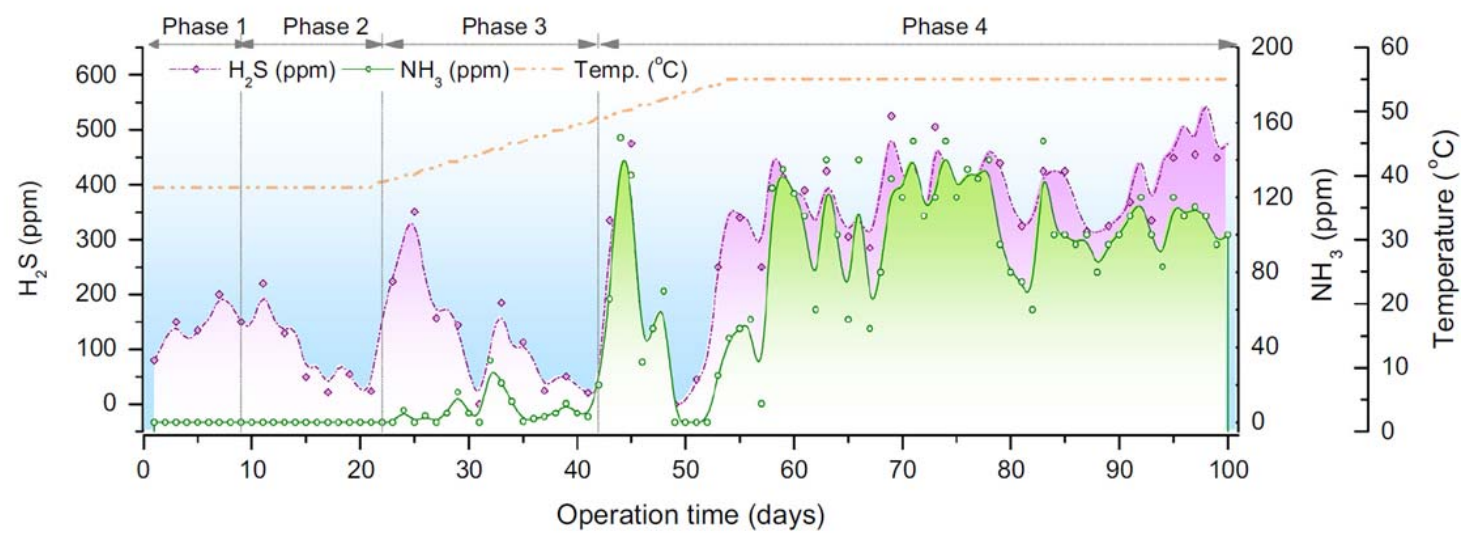

Fig. 4. Variation of $\mathrm{H}_{2} \mathrm{~S}$ and $\mathrm{NH}_{3}$ generated in the thermophilic anaerobic digester during operation.

Table 2 summarizes some of the key parameters used to monitor the process performance in this study. During the steady states of Phase 1, 2, 3, and 4, the average $\mathrm{H}_{2} \mathrm{~S}$ concentrations were $155 \pm 32.86 \mathrm{ppm}, 48.29 \pm 26.59 \mathrm{ppm}, 69.36 \pm 53.72 \mathrm{ppm}$, and $420 \pm 88.27 \mathrm{ppm}$, and the average $\mathrm{NH}_{3}$ concentrations were $0.0 \mathrm{ppm}, \quad 0.0 \mathrm{ppm}, \quad 8.5 \pm 10.14 \mathrm{ppm}$, and $106.71 \pm 21.94 \mathrm{ppm}$, respectively. However, the $\mathrm{H}_{2} \mathrm{~S}$ concentrations throughout the study period fluctuated from 0 to $587 \mathrm{ppm}$ and $\mathrm{NH}_{3}$ values from 0 to $152 \mathrm{ppm}$ although in general no significant inhibition effects were observed.

Table 2. Summary values of $\mathrm{TN}, \mathrm{NH}_{4}-\mathrm{N}, \mathrm{H}_{2} \mathrm{~S}$-gas, and $\mathrm{NH}_{3}$-gas during steady state operation of the thermophilic dry anaerobic digester by phase.

\begin{tabular}{|c|c|c|c|c|c|c|}
\hline \multirow[t]{2}{*}{ Phase } & \multirow{2}{*}{$\begin{array}{l}\begin{array}{l}\text { TN } \\
(\mathrm{mg} / \mathrm{L})\end{array} \\
\text { Avg. }\end{array}$} & \multirow{2}{*}{$\begin{array}{l}\begin{array}{l}\mathrm{NH}_{4}-\mathrm{N} \\
(\mathrm{mg} / \mathrm{L})\end{array} \\
\text { Avg. }\end{array}$} & \multicolumn{2}{|c|}{$\mathrm{NH}_{3}$-gas (ppm) } & \multicolumn{2}{|c|}{$\mathrm{H}_{2} \mathrm{~S}$-gas (ppm) } \\
\hline & & & $\begin{array}{l}\text { Min.- } \\
\text { Max. }\end{array}$ & Avg. \pm Stdev. & $\begin{array}{l}\text { Min.- } \\
\text { Max. }\end{array}$ & Avg. \pm Stdev \\
\hline 1 & 4500 & 1800 & $0-0$ & $0 \pm 0$ & $110-200$ & $155 \pm 32.86$ \\
\hline 2 & 5600 & 3200 & $0-0$ & $0 \pm 0$ & $22-83$ & $48.29 \pm 26.59$ \\
\hline 3 & 6200 & 3500 & $0-33$ & $6.48 \pm 8.42$ & $0-351$ & $128.85 \pm 97.19$ \\
\hline $\begin{array}{l}\text { Steady } \\
\text { state }\end{array}$ & 6200 & 3500 & $0-33$ & $8.5 \pm 10.14$ & $0-185$ & $69.36 \pm 53.72$ \\
\hline 4 & 6100 & 3600 & $0-152$ & $90.2 \pm 42.6$ & $0-587$ & $340.05 \pm 147.52$ \\
\hline $\begin{array}{l}\text { Steady } \\
\text { state }\end{array}$ & 6300 & 3700 & $80-120$ & $102.71 \pm 12.28$ & $310-587$ & $420 \pm 88.27$ \\
\hline
\end{tabular}

It has been reported that an ammonium concentration in the range of $1.5-3 \mathrm{~g} \mathrm{NH}_{4} \mathrm{~N} / \mathrm{L}$, and a $\mathrm{pH}$ greater than 7.4 in the digester may be detrimental to the AD process; in particular, an 
ammonium concentration over $3 \mathrm{~g} \mathrm{NH}_{4} \mathrm{~N} / \mathrm{L}$ is considered toxic to methanogenic bacteria irrespective of $\mathrm{pH}$ values [46]. Other studies [47] concluded that during the AD process, a complete inhibition occurred when ammonium concentrations were in the $8-13 \mathrm{~g} \mathrm{NH}_{4}-\mathrm{N} / \mathrm{L}$ range, depending on the level of acclimatization and the level of $\mathrm{pH}$ in the system.

$\mathrm{TN}$ and $\mathrm{NH}_{4}-\mathrm{N}$ concentrations in the samples from the thermophilic dry anaerobic digester in this study were found to be relatively high, gradually increasing from 4500 to $6300 \mathrm{mg} \mathrm{TN} / \mathrm{L}$, and from 1800 to $3700 \mathrm{mg} \mathrm{NH}_{4}-\mathrm{N} / \mathrm{L}$, respectively (Table 2). However, the inhibition of the microorganism populations or negative impacts on biogas and methane production were not observed. The varying degree of inhibition documented in previous studies could be explained by differences in feeding substrates, inoculums, conditions, acclimation periods, and other minor factors [42].

This result reaffirms that the frequently seen inhibitory effects of $\mathrm{TN}, \mathrm{NH}_{4}-\mathrm{N}, \mathrm{NH}_{3}$-gas, and $\mathrm{H}_{2} \mathrm{~S}$-gas on the performance of dry anaerobic digestion (under the conditions of increasing OLR and decreasing HRT) were not observed (with no intervention of any substrates or chemicals). This could be attributed to the combination of an adequate food waste fraction and a well-adapted anaerobic microorganism population that is resilient against the effects of toxic compounds or high loadings.

\subsection{Model simulation of full-scale plant operation under different OLRs}

Mathematical models are a powerful tool for predicting the system performance by describing the behavior of anaerobic microbes, the interactions of operating parameters, and the improvement of technical processes [48]. The values of cumulative biogas and methane production were measured and recorded each day during the operation of the dry anaerobic digester (Fig. 2c, symbol shapes). Subsequently, they were compared with the simulated data (Fig. 2c, solid lines) using the modified Gompertz equation (Eq. (1)).

The results obtained from the regression analysis of the modified Gompertz model (Table 3) showed a good fit to the experimental data at all phases by a statistically significant predictive model. It is evident that there was a very small difference between measured and predicted results (Fig. 2c) that yielded a small probability ( $p$ ) value, $p<0.001$, and a high coefficient of determination value, $\mathrm{R}^{2}>0.986$ (Table 3 ).

Table 3. Summary of fitted results for biogas and methane yields following the modified Gompertz model.

\begin{tabular}{|c|c|c|c|c|c|c|c|c|c|c|c|}
\hline \multirow{3}{*}{$\begin{array}{l}\text { Phas } \\
\text { e }\end{array}$} & \multirow{3}{*}{$\begin{array}{l}\text { OLR (kg- } \\
\text { VS/m } \mathbf{m}^{3} \text { da } \\
\text { y) }\end{array}$} & \multicolumn{2}{|l|}{$P$} & \multicolumn{2}{|l|}{$R m$} & \multicolumn{2}{|l|}{$\lambda$} & \multicolumn{2}{|c|}{$p$ - value } & \multicolumn{2}{|l|}{$R^{2}$} \\
\hline & & \multicolumn{2}{|c|}{$\left(\mathrm{L} / \mathrm{kg}-\mathrm{VS}_{\mathrm{added}}\right)$} & \multicolumn{2}{|c|}{$\begin{array}{l}\text { (L/kg- } \\
\mathrm{VS}_{\text {added }} \text { day) }\end{array}$} & \multicolumn{2}{|l|}{ (days) } & \multicolumn{2}{|l|}{-} & \multicolumn{2}{|l|}{-} \\
\hline & & Biogas & $\begin{array}{l}\text { Methan } \\
\text { e }\end{array}$ & $\begin{array}{l}\text { Bioga } \\
\mathrm{s}\end{array}$ & $\begin{array}{l}\text { Methan } \\
\text { e }\end{array}$ & $\begin{array}{l}\text { Bioga } \\
\mathrm{s}\end{array}$ & $\begin{array}{l}\text { Methan } \\
\text { e }\end{array}$ & Biogas & $\begin{array}{l}\text { Methan } \\
\text { e }\end{array}$ & $\begin{array}{l}\text { Bioga } \\
\text { S }\end{array}$ & $\begin{array}{l}\text { Methan } \\
\text { e }\end{array}$ \\
\hline
\end{tabular}




\begin{tabular}{|c|c|c|c|c|c|c|c|c|c|c|c|}
\hline \multirow[t]{2}{*}{1} & $2.16 \pm 0.0$ & 62.16 & 26.22 & 5.02 & 2.20 & 2.01 & 2.12 & $<0.000$ & $<0.000$ & 0.999 & 0.9997 \\
\hline & 8 & & & & & & & 1 & 1 & 8 & 0 \\
\hline \multirow[t]{2}{*}{2} & $3.58 \pm 0.1$ & 1248.46 & 659.99 & 23.32 & 14.76 & 8.84 & 8.84 & $<0.000$ & $<0.000$ & 0.986 & 0.9863 \\
\hline & 4 & & & & & & & 1 & 1 & 5 & 4 \\
\hline \multirow[t]{2}{*}{3} & $7.18 \pm 0.2$ & 2323.27 & 1628.15 & 38.73 & 23.01 & 0.25 & 2.00 & $<0.001$ & $<0.001$ & 0.999 & 0.9986 \\
\hline & 8 & & & & & & & & & 6 & 7 \\
\hline \multirow[t]{2}{*}{4} & $8.62 \pm 0.3$ & 30127.1 & 18590.5 & 102.3 & 61.70 & 30.16 & 34.93 & $<0.001$ & $<0.001$ & 0.999 & 0.9977 \\
\hline & 4 & 3 & 1 & 8 & & & & & & 2 & 7 \\
\hline
\end{tabular}

Based on the results of the regression analysis using the Gompertz model, the variation of specific gas production potential $(\mathrm{P})$, the maximum gas production rate $(\mathrm{Rm})$, and the minimum time taken to produce biogas ( $\lambda$, lag phase time) versus OLRs are illustrated in Fig. 5.
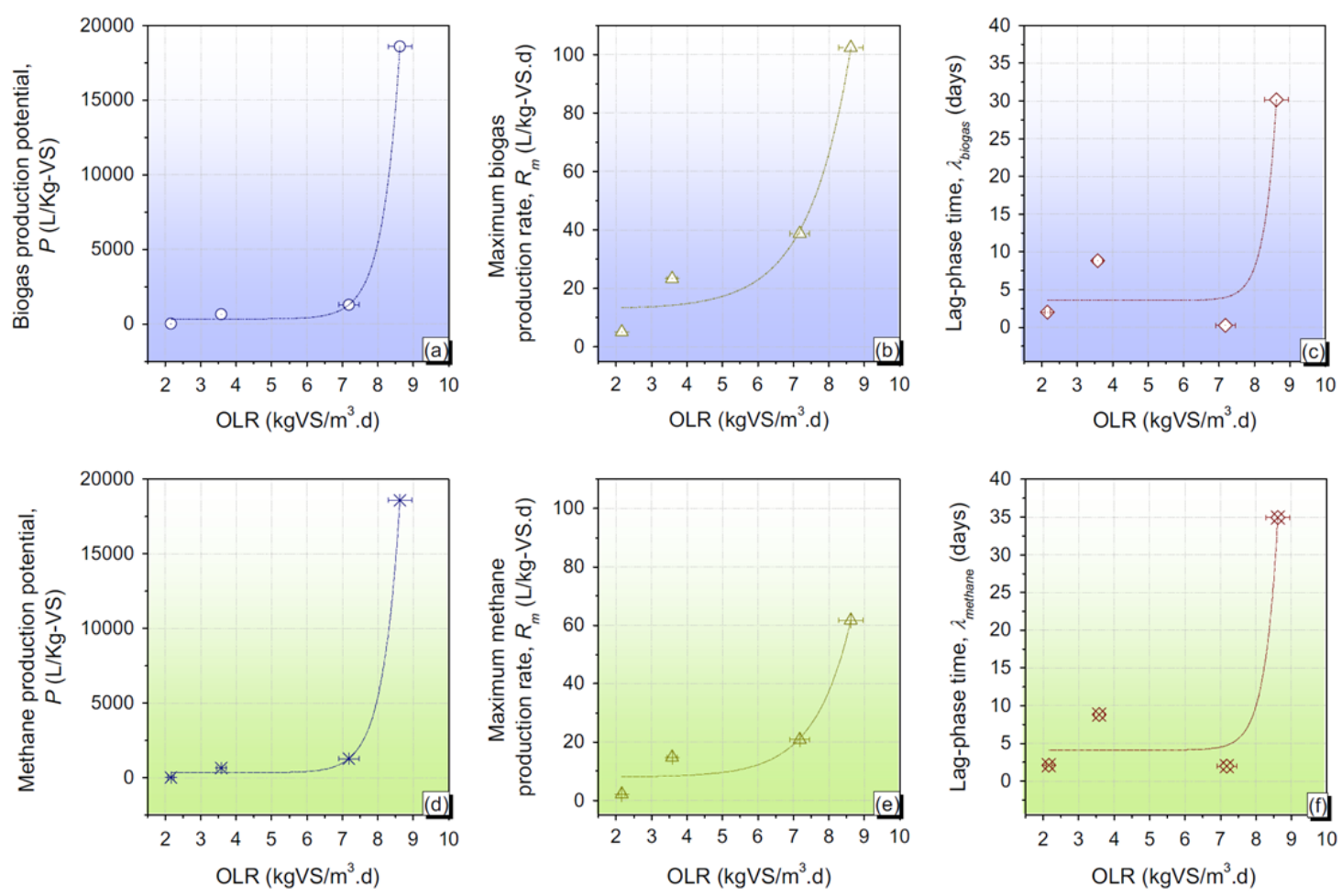

Fig. 5. Linear plots of specific biogas and methane production potentials $(\mathrm{P})$, the maximum biogas/methane production rates $(\mathrm{Rm})$, and the duration of lag phase $(\lambda)$ at different OLRs.

Simulation results shown in Fig. 5 indicate the variations of $\mathrm{P}, \mathrm{Rm}$, and $\lambda$ under different OLRs and are completely consistent with the experimental data, reflecting that the $\mathrm{P}, \mathrm{Rm}$, and $\lambda$ increased proportionally with increasing OLR. When the system was operated with an OLR of $2.0-7.5 \mathrm{~kg}-\mathrm{VS} / \mathrm{m}^{3}$ day, the bacterial acclimatization to the new environment occurred quite rapidly, within 3-5 days. In contrast, when the OLR was greater than $8.4 \mathrm{~kg}-\mathrm{VS} / \mathrm{m}^{3}$ day, the bacteria's acclimatization to the new environment occurred more slowly, over 20 days. 
These results suggest that the dry digester should be operated in the OLR range of 7.5$8.4 \mathrm{~kg}-\mathrm{VS} / \mathrm{m}^{3}$ day.

Additionally, the results of the kinetic parameters obtained from the regression analysis can be used to predict the biogas or methane production potential, the maximum specific biogas or methane production rate, and the minimum time needed for anaerobic microorganisms to acclimatize to the environment, under the specific operating conditions of OLR. The ability to predict these factors has significant practical applications to the real-world food waste treatment methods that use thermophilic dry anaerobic digesters. These findings demonstrate that, by increasing the OLR, digesters already in use can treat more FW and increase the energy production without expanding their reactors.

\subsection{Energy balance and cost estimates}

The experimental and modeling results discussed above indicate that the thermophilic DScAD of food waste is technologically feasible and can considerably enhance the biomethane production and sludge reduction. This technology choice is practical from the perspective of technical capability, economics, and the energy recovery potential. This study confirmed that there is a balance between the energy consumption and the energy recovery potential, in order to maximize the self-sufficiency and minimize the energy requirements.

The energy consumption by the thermophilic DScAD system, $\mathrm{E}_{\mathrm{EC}}(\mathrm{kW} \mathrm{h} /$ day), was the total energy of all devices used in the system (pumping, mixing, and heating) (Eq. (2)).

$E_{\mathrm{EC}}(\mathrm{kW} \mathrm{h} /$ day $)=E_{\text {Mixing }}+E_{\text {Pumping }}+E_{\text {Heating }}$

where $\mathrm{E}_{\text {Mixing }}(\mathrm{kWh} /$ day $), \mathrm{E}_{\text {Pumping }}(\mathrm{kWh}$ /day $)$, and $\mathrm{E}_{\text {Heating }}(\mathrm{kW} \mathrm{h/day)} \mathrm{denote} \mathrm{the} \mathrm{energy}$ used for mixing, pumping, and heating, respectively.

The total additional energy supply, $\mathrm{E}_{\mathrm{ES}}(\mathrm{kW} \mathrm{h} /$ day), to the DScAD system is given in Eq.(3),

$$
E_{\mathrm{ES}}(\mathrm{kW} \mathrm{h} / \text { day })=E_{\mathrm{EC}}-E_{\text {Biogas }}
$$

where $\mathrm{E}_{\text {Biogas }}(\mathrm{kW} \mathrm{h/day)}$ is the energy potential of the biogas produced.

The specific energy supply, $\mathrm{E}_{\mathrm{sp}}(\mathrm{kWh}$ /ton of food waste), which represents the ratio of the total energy consumed to the total food waste processed in a day, is shown in Eq. (4).

$$
E_{s p}(\mathrm{~kW} \mathrm{~h} / \text { ton })=\frac{E_{E C}(\mathrm{~kW} \mathrm{~h} / \text { day })}{\text { Treatment capacity }(\text { ton } / \text { day })}
$$

Estimated energy consumption, energy recovery, and cost analysis associated with the thermophilic DScAD performance is shown in Fig. 6 (more details are provided in Table S1). The results of the regression analysis yielded a very good fit to first-order linear relationships between the energy recovery (Fig. 6a), total additional energy supply (Fig. 6b), specific energy supply (Fig. 6c), and specific treatment cost of FW (Fig. 6d) with OLRs, with 
reasonably high values of coefficients of determination $\left(\mathrm{R}^{2}\right)$. The functions of the curve fitting graphically illustrated in Fig. 6 can correctly predict and optimize the recovered energy via methane production, specific energy input, and the average power consumption cost to treat 1 ton of food waste of dry anaerobic digester, as a function of the OLR applied.
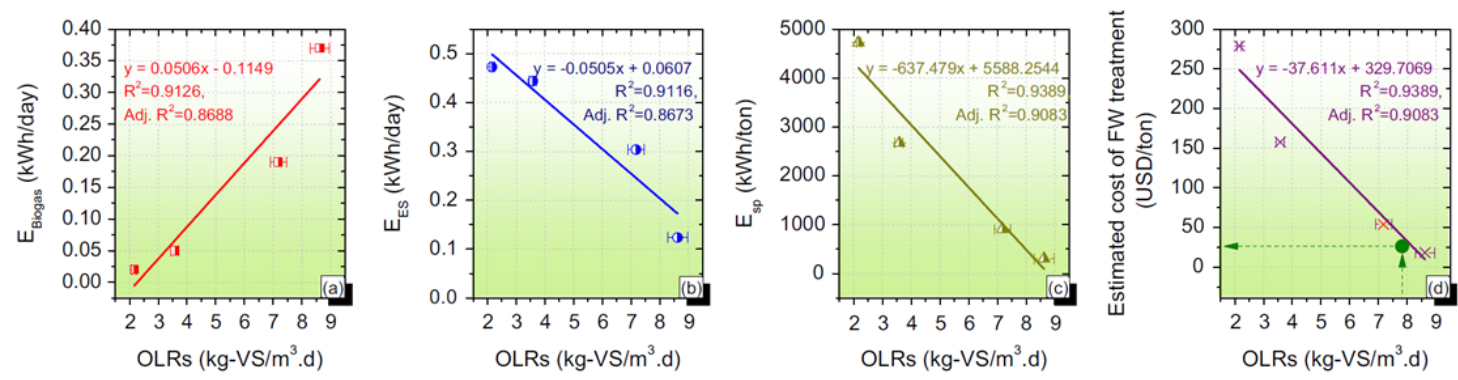

Fig. 6. Energy consumption, recovery potential from biogas, and cost estimation at different OLRs with standard deviation.

It was also observed that the energy recovery increased proportionally with increasing OLR, whereas the total additional energy supply, specific energy supply, and specific treatment cost of FW decreased with increased OLR.

Energy balance analyses indicated that, depending on the environmental temperature, the daily electrical energy required to operate the thermophilic dry digester varied from 0.423 to $0.567 \mathrm{~kW} \mathrm{~h}$. The thermal energy required to heat the sludge to thermophilic conditions accounted for approximately $60-71 \%$ of the total energy consumption.

Furthermore, depending on the operating load of organic matter, which increased from 2.16 to $8.62 \mathrm{~kg}-\mathrm{VS} / \mathrm{m}^{3}, 4.3-75 \%$ of total energy requirement to operate the DScAD system was recovered via renewable energy production (assuming the conversion factor of $1 \mathrm{~m}^{3}$ methane was equivalent to $10 \mathrm{~kW} \mathrm{~h}$ ). It means that the additional energy supply needed to operate the DScAD process varied from 0.473 to $0.12 \mathrm{~kW} \mathrm{~h}$ /day and the specific energy consumption per ton of FW treated varied from 309.31 to $4727.26 \mathrm{~kW} \mathrm{h/ton}$. Consequently, the maximum recoverable electrical energy from a $1 \mathrm{~m}^{3}$ effective dry digester was $15,330 \mathrm{~kW} \mathrm{~h} /$ year (average $13,505 \mathrm{~kW} \mathrm{~h} /$ year, equivalent to 1.161 tons of oil/year) at the operating conditions with an OLR of $8.62 \mathrm{~kg}-\mathrm{VS} / \mathrm{m}^{3}$ day and HRT of 25 days. It was about 11.6 times higher than the one reported by [49] in a full-scale anaerobic digestion plant for fruit and vegetable waste. The results revealed a good potential for thermophilic dry AD applications in FW treatment, for renewable energy recovery, and energy self-sufficiency.

An economic analysis indicated that the average treatment cost for the thermophilic DScAD system varied from 18.25 to 278.91 US \$/ton of food waste treated (assuming the current price for the electric supply was 0.059 USD per $1 \mathrm{~kW} \mathrm{~h}$ ). Meanwhile, other studies reported 310 US \$/ton of sludge for landfill hauling and disposal contract cost [50], 176 US \$/ton of sludge treated [51], 100-300 US \$/ton of sludge for an $\mathrm{AFC}^{\mathrm{SM}}$ system, and 200-500 US\$/ton sludge for conventional technologies [52]. In the light of these results, a thermophilic dry AD system should be operated at a high loading in order to enhance simultaneous renewable 
energy production and treatment efficiency. Doing so will allow the system to reduce digestion time, required digester volume, and environmental impacts, and minimize the additional energy supply needed to operate the equipment.

\section{Conclusions}

An integrated thermophilic DScAD system has been modeled and comprehensively evaluated by considering technical operations and economic costs. We conclude that utilizing this technology for solids reduction and biomethane production could be an appropriate alternative energy solution in South Korea for the effective treatment of and high renewable energy recovery from food waste. The experimental results for biogas and methane production agreed well with the regression analysis of the modified Gompertz model. The OLR has a significant effect on the thermophilic dry AD system performance. For approximately fourfold increase in OLRs (from $2.3 \pm 0.22$ to $9.21 \pm 0.89 \mathrm{~kg}-\mathrm{VS} / \mathrm{m}^{3}$ day), the average VS reduction rate increased 1.8-fold (from $48.77 \pm 1.27$ to $81.19 \pm 2.68 \%$ ), the

average biomethane generation rate increased 3.8-fold (from 43.33 \pm 8.16 to $162.14 \pm 4.58 \mathrm{~m}^{3}$ biogas/ton), adaptation time increased 16-fold (from $2 \pm 1$ days to $31 \pm 4$ days), and the average renewable energy recovery increased 5.4-fold (from $672 \pm 150.23$ to $3611.57 \pm 165.22 \mathrm{MJ} /$ ton $\mathrm{FW}$ ). These results suggest that the long-sought goal of a suitable solution for treating FW in South Korea has finally been achieved.

\section{Acknowledgements}

This work was conducted under the framework of Research and Development Program of the Korea Institute of Energy Research (KIER). The authors are grateful for the research collaboration between Kyonggi University and University of Technology Sydney. The authors also thank Mr. J.H. Cha for his research assistance with this project.

[1] Kothari R, Tyagi VV, Pathak A. Waste-to-energy: a way from renewable energy sources to sustainable development. Renew Sustain Energy Rev 2010;14:3164-70.

[2] Zhang R, El-Mashad HM, Hartman K, Wang F, Liu G, Choate C, et al. Characterization of food waste as feedstock for anaerobic digestion. Bioresour Technol 2007;98:929-35.

[3] Scano EA, Asquer C, Pistis A, Ortu L, Demontis V, Cocco D. Biogas from anaerobic digestion of fruit and vegetable wastes: experimental results on pilot-scale and preliminary performance evaluation of a full-scale power plant. Energy Convers Manage 2014;77:22-30.

[4] Elsayed M, Andres Y, Blel W, Gad A, Ahmed A. Effect of VS organic loads and buckwheat husk on methane production by anaerobic co-digestion of primary sludge and wheat straw. Energy Convers Manage 2016;117:538-47.

[5] Moriarty K. Feasibility study of anaerobic digestion of food waste in St. Bernard, Louisiana. National Renewable Energy Laboratory-Technical Report; 2013. 
[6] Browne JD, Allen E, Murphy JD. Assessing the variability in biomethane production from the organic fraction of municipal solid waste in batch and continuous operation. Appl Energy 2014;128:307-14.

[7] Wu L-J, Kobayashi T, Li Y-Y, Xu K-Q. Comparison of single-stage and temperaturephased two-stage anaerobic digestion of oily food waste. Energy Convers Manage 2015;106:1174-82.

[8] Luz FC, Rocha MH, Lora EES, Venturini OJ, Andrade RV, Leme MMV, et al. Technoeconomic analysis of municipal solid waste gasification for electricity generation in Brazil. Energy Convers Manage 2015;103:321-37.

[9] W.M.R.B. Korea Ministry of Environment. Korea Ministry of Environment; 2016.

[10] Cho S-K, Im W-T, Kim D-H, Kim M-H, Shin H-S, Oh S-E. Dry anaerobic digestion of food waste under mesophilic conditions: performance and methanogenic community analysis. Bioresour Technol 2013;131:210-7.

[11] K.M.o. Environment. Waste-to-Energy (Current policy focus). Republic of Korea; 2014.

[12] Li M, Zhao Y, Guo Q, Qian X, Niu D. Bio-hydrogen production from food waste and sewage sludge in the presence of aged refuse excavated from refuse landfill. Renew Energy 2008;33:2573-9.

[13] Chasek PS, Downie DL, Brown J. Global environmental politics. Westview Press; 2013.

[14] Kim D-H, Kim S-H, Shin H-S. Hydrogen fermentation of food waste without inoculum addition. Enzyme Microb Technol 2009;45:181-7.

[15] Karthikeyan OP, Visvanathan C. Bio-energy recovery from high-solid organic substrates by dry anaerobic bio-conversion processes: a review. Rev Environ Sci Bio/Technol 2013;12:257-84.

[16] Kothari R, Pandey AK, Kumar S, Tyagi VV, Tyagi SK. Different aspects of dry anaerobic digestion for bio-energy: an overview. Renew Sustain Energy Rev 2014;39:17495.

[17] Silvestre G, Fernández B, Bonmatí A. Significance of anaerobic digestion as a source of clean energy in wastewater treatment plants. Energy Convers Manage 2015;101:255-62.

[18] Kim D-H, Oh S-E. Continuous high-solids anaerobic co-digestion of organic solid wastes under mesophilic conditions. Waste Manage 2011;31:1943-8.

[19] Forster-Carneiro T, Pérez M, Romero L, Sales D. Dry-thermophilic anaerobic digestion of organic fraction of the municipal solid waste: focusing on the inoculum sources. Bioresour Technol 2007;98:3195-203.

[20] Li C, Mörtelmaier C, Winter J, Gallert C. Effect of moisture of municipal biowaste on start-up and efficiency of mesophilic and thermophilic dry anaerobic digestion. Bioresour Technol 2014;168:23-32. 
[21] Fernández J, Pérez M, Romero LI. Effect of substrate concentration on dry mesophilic anaerobic digestion of organic fraction of municipal solid waste (OFMSW). Bioresour Technol 2008;99:6075-80.

[22] Elsamadony M, Tawfik A, Suzuki M. Surfactant-enhanced biohydrogen production from organic fraction of municipal solid waste (OFMSW) via dry anaerobic digestion. Appl Energy 2015;149:272-82.

[23] Panepinto D, Fiore S, Zappone M, Genon G, Meucci L. Evaluation of the energy efficiency of a large wastewater treatment plant in Italy. Appl Energy 2016;161:404-11.

[24] Angelidaki I, Alves M, Bolzonella D, Borzacconi L, Campos JL, Guwy AJ, et al. Defining the biomethane potential (BMP) of solid organic wastes and energy crops: a proposed protocol for batch assays. Water Sci Technol 2009;59:927-34.

[25] A. Apha. WEF, 2005. Standard methods for the examination of water and wastewater, vol. $21 ; 2005$. p. $258-9$

[26] Zwietering M, Jongenburger I, Rombouts F, Van't Riet K. Modeling of the bacterial growth curve. Appl Environ Microbiol 1990;56:1875-81.

[27] Zhao M-X, Ruan W-Q. Biogas performance from co-digestion of Taihu algae and kitchen wastes. Energy Convers Manage 2013;75:21-4.

[28] Kafle GK, Kim SH. Anaerobic treatment of apple waste with swine manure for biogas production: batch and continuous operation. Appl Energy 2013;103:61-72.

[29] Lu X, Zhen G, Liu Y, Hojo T, Estrada AL, Li Y-Y. Long-term effect of the antibiotic cefalexin on methane production during waste activated sludge anaerobic digestion. Bioresour Technol 2014;169:644-51.

[30] Kim MH, Song HB, Song Y, Jeong IT, Kim JW. Evaluation of food waste disposal options in terms of global warming and energy recovery: Korea. Int J Energy Environ Eng 2013;4:1-12.

[31] Koch K, Plabst M, Schmidt A, Helmreich B, Drewes JE. Co-digestion of food waste in a municipal wastewater treatment plant: comparison of batch tests and full-scale experiences. Waste Manage 2016;47(Part A):28-33.

[32] Zhang C, Su H, Baeyens J, Tan T. Reviewing the anaerobic digestion of food waste for biogas production. Renew Sustain Energy Rev 2014;38:383-92.

[33] Micolucci F, Gottardo M, Cavinato C, Pavan P, Bolzonella D. Mesophilic and thermophilic anaerobic digestion of the liquid fraction of pressed biowaste for high energy yields recovery. Waste Manage 2016;48:227-35.

[34] Pham TN, Nam WJ, Jeon YJ, Yoon HH. Volatile fatty acids production from marine macroalgae by anaerobic fermentation. Bioresour Technol 2012;124:500-3. 
[35] Aramrueang N, Rapport J, Zhang R. Effects of hydraulic retention time and organic loading rate on performance and stability of anaerobic digestion of Spirulina platensis. Biosyst Eng 2016;147:174-82.

[36] Buyukkamaci N, Filibeli A. Volatile fatty acid formation in an anaerobic hybrid reactor. Process Biochem 2004;39:1491-4.

[37] Zhao M-X, Ruan W-Q. Improving hydrogen generation from kitchen wastes by microbial acetate tolerance response. Energy Convers Manage 2014;77:419-23.

[38] Gao S, Huang Y, Yang L, Wang H, Zhao M, Xu Z, et al. Evaluation the anaerobic digestion performance of solid residual kitchen waste by NaHCO3 buffering. Energy Convers Manage 2015;93:166-74.

[39] Zhang C, Su H, Tan T. Batch and semi-continuous anaerobic digestion of food waste in a dual solid-liquid system. Bioresour Technol 2013;145:10-6.

[40] Marchaim U, Krause C. Propionic to acetic acid ratios in overloaded anaerobic digestion. Bioresour Technol 1993;43:195-203.

[41] Chen Y, Cheng JJ, Creamer KS. Inhibition of anaerobic digestion process: a review. Bioresour Technol 2008;99:4044-64.

[42] Bishnoi P. Effects of thermal hydrolysis pre-treatment on anaerobic digestion of sludge. Virginia Polytechnic Institute and State University; 2012.

[43] Qian L, Wang S, Xu D, Guo Y, Tang X, Wang L. Treatment of municipal sewage sludge in supercritical water: a review. Water Res 2016;89:118-31.

[44] Lettinga G, Pol LH, Koster I, Wiegant W, De Zeeuw W, Rinzema A, et al. Highrate anaerobic waste-water treatment using the UASB reactor under a wide range of temperature conditions. Biotechnol Genet Eng Rev 1984;2:253-84.

[45] Ali Shah F, Mahmood Q, Maroof Shah M, Pervez A, Ahmad Asad S. Microbial ecology of anaerobic digesters: the key players of anaerobiosis. Sci World J 2014;2014.

[46] Calli B, Mertoglu B, Inanc B, Yenigun O. Effects of high free ammonia concentrations on the performances of anaerobic bioreactors. Process Biochem 2005;40:1285-92.

[47] Sung S, Liu T. Ammonia inhibition on thermophilic anaerobic digestion. Chemosphere 2003;53:43-52.

[48] Xu F, Li Y, Wang Z-W. Mathematical modeling of solid-state anaerobic digestion. Prog Energy Combust Sci 2015;51:49-66.

[49] Di Maria F, Sordi A, Cirulli G, Micale C. Amount of energy recoverable from an existing sludge digester with the co-digestion with fruit and vegetable waste at reduced retention time. Appl Energy 2015;150:9-14.

[50] Mahmood T, Elliott A. A review of secondary sludge reduction technologies for the pulp and paper industry. Water Res 2006;40:2093-112. 
[51] N.R.C.C.M.A.M.S. Management, U.S.E.P. Agency. Multimedium Management of Municipal Sludge: A Report to the U.S. Environmental Protection Agency from the Committee on a Multimedium Approach to Municipal Sludge Management, Commission on Natural Resources, National Research Council. National Academy of Sciences; 1978.

[52] P. BioTec. Destroy Municipal sludge, Save Money or Make Profit and Improve environmental Public Relations; 2008. 